DOI: 10.2478/v10014-008-0001-x

Agrovoc descriptors: oil crops, brassica napus, proximate composition, gypsum, potassium sulphate, proteins, fatty acids, oils, fertilizer application

Agris category codes: F04, F60, FO1

Slovenian Institute of Hop Research and Brewing

Cesta Žalskega tabora 2

3310 Žalec

\title{
Impact of source and application time of sulphur on the yield, oil content and protein content in winter oilseed rape
}

\author{
Barbara ČEH ${ }^{1}$, Robert HRASTAR ${ }^{2}$, Anton TAJNŠEK ${ }^{3}$, Iztok Jože KOŠIR ${ }^{4}$
}

Received March 29, 2008; accepted April 29, 2008.

Delo je prispelo 29. marca 2008; sprejeto 29. aprila 2008.

\begin{abstract}
At the experimental field of Slovenian Institute of Hop Research and Brewing at Žalec an experiment was conducted in 2006/07 to detect the impact of fertilization by $\mathrm{K}_{2} \mathrm{SO}_{4}$ and gypsum on the yield, oil content, oil yield, protein content, protein yield and fatty acids composition at two different cultivars of oilseed rape (cultivar Smart and hybrid Toccata). In the conditions of the experiment the source of sulphur did not impact the yield, but a negative impact of spring fertilization by sulphur at cultivar Smart was detected. At hybrid Toccata positive impact of gypsum was detected when it was fertilized at sowing. Oil content was higher at cultivar Smart by $3.32 \%$ compared to hybrid Toccata. At cultivar Smart no source of sulphur impacted significantly the yield of oil, while at the conditions of the experiment positive impact of spring applications of sulphur on the yield of oil was detected at hybrid Toccata. Oil yield was higher at cultivar Smart compared to hybrid Toccata. Protein content was not impacted by sulphur fertilization. The share of linoleic acid was higher at hybrid Toccata by $2.2 \%$ to $2.4 \%$, the share of oleic acid was higher at cultivar Smart by $2.2 \%$ to $3.1 \%$, the shares of other investigated acids did not differ a lot between Smart and Toccata.
\end{abstract}

Key words: gypsum, potassium sulphate, winter oilseed rape, oil, protein, yield, fatty acids, fertilization

1 Assist. Prof., PhD., Slovenian Institute of Hop Research and Brewing, Cesta Žalskega tabora 2, 3310 Žalec, Slovenia, e-mail: barbara.ceh@ihps.si

2 BSc., Slovenian Institute of Hop Research and Brewing, Cesta Žalskega tabora 2, 3310 Žalec, Slovenia, e-mail: robert.hrastar@ihps.si

3 Prof., PhD., University of Ljubljana, Biotechnical Faculty, Jamnikarjeva 101, Ljubljana, Slovenia; e-mail: tone.tajnsek@bf.uni-lj.si

4 PhD., Slovenian Institute of Hop Research and Brewing, Cesta Žalskega tabora 2, 3310 Žalec, Slovenia, e-mail: iztok.kosir@ihps.si 


\section{IZVLEČEK}

\section{VPLIV OBLIKE TER ČASA APLIKACIJE ŽVEPLA NA PRIDELEK IN VSEBNOST OLJA TER BELJAKOVIN PRI OZIMNI OLJNI OGRŠČICI}

Na poskusnem polju Inštituta za hmeljarstvo in pivovarstvo Slovenije $v$ Žalcu smo $v$ sezoni $2006 / 07$ zastavili poskus, v katerem smo preizkusili vpliv gnojenja s $\mathrm{K}_{2} \mathrm{SO}_{4}$ in sadro na pridelek, vsebnost olja, pridelek olja, vsebnost beljakovin, pridelek beljakovin in sestavo maščobnih kislin dveh kultivarjev (kultivar Smart in hibrid Toccata) oljne ogrščice. $V$ danih razmerah različne oblike gnojenja z žveplom niso imele značilnega vpliva na pridelek, vendar se pri kultivarju Smart nakazuje negativen učinek spomladanskega gnojenja z gnojili, ki vsebujejo žveplo, pri hibridu Toccata pa pozitiven učinek gnojenja s sadro, če je bila pognojena ob setvi. Vsebnost olja je bila pri kultivarju Smart za 3,32\% višja kot pri hibridu Toccata. Pri kultivarju Smart nobena oblika gnojenja z žveplom ni pomembno vplivala na hektarski pridelek olja, pri hibridu Toccata pa se $v$ danih razmerah nakazuje pozitiven učinek spomladanskega gnojenja z žveplom na pridelek olja. Hektarski pridelek olja je pomembno večji pri kultivarju Smart kot pri hibridu Toccata. Na vsebnost beljakovin gnojenje z žveplom ni imelo vpliva. Delež linolne kisline $v$ olju je bil pri hibridu Toccata višji za $2,2 \%$ do $2,4 \%$, delež oleinske kisline je bil višji pri kultivarju Smart za 2,2 do 3,1\%, deleži drugih maščobnih kislin se pri obeh kultivarjih medsebojno le malo razlikujejo.

Ključne besede: sadra, kalijev sulfat, oljna ogrščica, olje, beljakovine, pridelek, maščobne kisline, gnojenje

\section{INTRODUCTION}

To maintain a balanced $\mathrm{N}$ and $\mathrm{S}$ supply for yield and quality was stressed at oilseed rape (Zhao et al., 1997; Ahmad et al., 1999; McGrath and Zhao, 1996). According to Ahmad et al. (1999) applications of $\mathrm{N}$ in split doses and $\mathrm{S}$ as a basal dose may create imbalance in the supply of these nutrients during the growth and development of the crop because metabolism of $\mathrm{N}$ and that of $\mathrm{S}$ are closely linked and play a central role in protein synthesis. In their experiment $\mathrm{S}$ was applied $(40 \mathrm{~kg} / \mathrm{ha} \mathrm{S}$ in the form of gypsum) in split doses along with $\mathrm{N}$ at Brassica juncea L. and Brassica campestris L. On the basis of results it was concluded that $\mathrm{S}$ must be applied in split doses for optimum growth and yield of Brassica genotypes. Also, genetic variability was observed between the two genotypes in response to split application of S and $\mathrm{N}$. The positive impact of $S$ on seed yield at oilseed rape was achieved mainly through reduced pod abortion (Zhao et al., 1993).

In the experiment by Singh and Aggarwal (1998) gypsum applications reflected in better pod length, sees/pod, TGW, protein content and yield of blackgram (Phaseolus mungo) compared to the other source of sulphur tested (elemental S, pyrite, gypsum). On the other hand pyrite applications reflected in higher yields compared to gypsum applications at clusterbean (Cyamopsis tetragonoloba) in the experiment by Shekhawat et al. (1996); the increasing levels of sulphur from $0 \mathrm{~kg} / \mathrm{ha}$ to $40 \mathrm{~kg} / \mathrm{ha}$ increased grains/pod. In the combination with NPK fertilizers gypsum applications reflected in significant improvement in yield of groundnut (Arachis hypogaea L.) (Prasad et al., 2002). On the other hand, in the experiment by Moreira et al. (1998) the $\mathrm{S}$ source (gypsum and $\mathrm{K}_{2} \mathrm{SO}_{4}$ ) did not affect yield of white clover (Trifolium repens). Among the sources of sulphur, gypsum proved significantly superior with respect to yield attributes (pod/plant and TGW), grain and straw yields 
and harvest index at different cultivars of lentil (Lens culinaris) in the experiment by Singh and Chauhan (2002). Gypsum applications $(250 \mathrm{~kg} / \mathrm{ha})$ reflected in significant improvement in yield attributes and seed yield of Indian mustard (Brassica juncea L.) (Rao and Shaktawat, 2002). In the experiment by Samui and Bandopadhyay (1997) application of sulphur through gypsum significantly increased seed yield and oil yield at Indian mustard compared to pyrite. An increase in S level significantly increased the seed yield $(0-50 \mathrm{~kg} / \mathrm{ha} \mathrm{S})$. On the other hand the source of sulphur (gypsum, elemental S, pyrite) did not influence the growth, yield attributes and yields as well as quantity of Indian mustard (Brassica juncea L.) in the experiment by Kumar et al. (2001). Applications of 40 and $60 \mathrm{~kg} / \mathrm{ha} \mathrm{S} \mathrm{gave} \mathrm{significantly} \mathrm{higher}$ yield and quality (protein and oil contents in seed) over $20 \mathrm{~kg} / \mathrm{ha}$ and no $\mathrm{S}$ applications.

Kowalenko (2004) investigated response of forage grass to sulphur applications on coastal British Columbia soils. In his experiments spring gypsum applications increased yield in two and decreased yield in one of six trials. Powdered elemental S was available to plants sooner than an elemental $\mathrm{S}$ fertilizer, but neither as quickly as gypsum. In the experiment by Sanderson and Carter (2002) gypsum increased the $\mathrm{S}$ content of rutabaga leaf tissue and reduced soil $\mathrm{pH}$, at the same time marketable yield of rutabagas was not affected by addition of $\mathrm{Ca}$ and $\mathrm{S}$ amendments on sandy loam to loamy sand Podzols. The effect of gypsum as a sulphur fertilizer on the yield and growth was tested also on other crops, such as sunflower (Helianthus annuus L.) (Intodia and Tomar, 1997), cabbage (Brassica oleracea L. var. capitata) (Sandreson et al., 1996), cereals (Withers et al., 1995).

In the experiment of Hamza and Andreson (2002) the impact of gypsum on solving problems with soil compaction on clay soil with massive soil structure was investigated. Its application (2.5 t/ha) increased water-stable aggregates, the combination of soil ripping and gypsum application in the presence of complete nutrients and annual return of crop residues to the soil was suggested to improve crop grain yield and soil physical fertility on a range of Western Australian soils. Grain yields (wheat and legumes) were increased slightly more on the loamy sand soil than on the sandy clay loam soil due to deep ripping and gypsum application (Hamza and Andreson, 2003). By Fageria and Baligar (2001) in tropical acid soils adequate gypsum use is one of the factors to improve nutrient use efficiency by annual crops.

It can be seen from the literature cited that gypsum $\left(\mathrm{CaSO}_{4}() .2 \mathrm{H}_{2} \mathrm{O}\right)$ is tested in field experiments mainly as an aggregating agent and as a sulphur fertilizer. In the presented investigation gypsum was used as a sulphur fertilizer in the production of winter oilseed rape (Brassica napus L. var. napus); its impact on the seed yield, oil content, oil yield, protein content and protein yield was compared to another source of sulphur $\left(\mathrm{K}_{2} \mathrm{SO}_{4}\right)$. Fertilization by $\mathrm{S}$ at sowing and in spring were compared, split dose of $\mathrm{S}$ applied by gypsum was included. Response of two different genotypes (cultivar Smart and hybrid Toccata) was detected. 


\section{MATERIAL AND METHODS}

\subsection{Experimental layout}

The experiment was conducted at the experimental field of Slovenian Institute of Hop Research and Brewing in the season 2006-2007 as a block trial with three replications. The size of plots was $40 \mathrm{~m}^{2}$. There were two winter oilseed rapes sown: cultivar Smart $\left(65\right.$ plants $\left./ \mathrm{m}^{2}\right)$ and hybrid Toccata $\left(50\right.$ plants $\left./ \mathrm{m}^{2}\right)$. Six different treatments were compared:

- No fertilization by sulphur;

- Sulphur in the form of gypsum applied at sowing $(50 \mathrm{~kg} / \mathrm{ha} \mathrm{S})$;

- Sulphur in the form of $\mathrm{K}_{2} \mathrm{SO}_{4}$ applied at sowing $(50 \mathrm{~kg} / \mathrm{ha} \mathrm{S})$;

- Sulphur in the form of gypsum applied in spring (50 kg/ha S);

- Sulphur in the form of $\mathrm{K}_{2} \mathrm{SO}_{4}$ applied in spring $(50 \mathrm{~kg} / \mathrm{ha} \mathrm{S})$;

- Sulphur in the form of gypsum applied at sowing (20 kg/ha S) and in spring (30 kg/ha S).

Gypsum was a product of Cinkarna Celje d.d., its composition is stated in Table 1.

Table 1: Composition of gypsum, used in the experiment, produced at Cinkarna Celje d.d.

\begin{tabular}{ccccccccc}
\hline $\begin{array}{c}\mathrm{SO}_{4^{-}} \\
(\%)\end{array}$ & $\mathrm{Ca}(\%)$ & $\mathrm{Al}(\%)$ & $\mathrm{Cr}(\%)$ & $\mathrm{Cu}(\%)$ & $\mathrm{Fe}(\%)$ & $\mathrm{Mn}(\%)$ & $\mathrm{Ti}(\%)$ & $\mathrm{Zn}(\%)$ \\
\hline 55.6 & 23.0 & 0.008 & 0.005 & $<0.001$ & 0.13 & 0.001 & 0.24 & 0.001 \\
\hline
\end{tabular}

The experiment was treated according to the good agricultural practice; all the other agrotechnical arrangements except sulphur fertilization were the same for all plots and performed by machines. Sulphur fertilization was performed manually by plots. At the time of maturity experimental field was harvested plot by plot by the plot combine. Yield was weighted; samples of grain to analyse moisture, oil content and protein content were taken.

\subsection{Chemical analyses}

Moisture content was detected according to ISO 665:1977. Oil content was determined according to ISO 659:1998; oil is extracted out of grinded seeds by a solvent (hexan). After four hours solvent is removed by rotavapour. Fatty acids in oil were derivatized with BF3 to its methyl esters and detected by gas chromatograf (Flame lonization Detector) according to the method by Hamilnton and Hamilton. Protein content was determined according to the method by Kjeldahl. The method consists of heating a substance with sulfuric acid which decomposes the organic nitrogen present to ammonium sulfate.

\subsection{Processing of statistical data}

Results were statistically processed by the computer program Statgraphics for block trial in three replications, differences among treatments were detected by Duncan multiple range test $(p<0.05)$.

\subsection{Weather and soil conditions}

Autumn and winter in the season 2006/07 were rather warm compared to the long term average; growth of plants was fast in autumn, a good rosette form was reached before winter, growth was stopped for only a short time in January. January was warmer for some degrees compared to the long term average. February was the second warmest in last 50 years. In the first two decades of March relatively high temperatures continued, while after $19^{\text {th }}$ March it was cooled down and there was snow cower for four days. At that time stems of plants of hybrid Toccata were broken; up to $20 \%$ at the treatments where $\mathrm{K}_{2} \mathrm{SO}_{4}$ and gypsum were applied in spring. Plants recovered and new stems were formed. There was no damage caused by snow at the cultivar Smart, because plants were still in the rosette form at that time. Mean temperature in April was $13.1^{\circ} \mathrm{C}$, in May $16.4^{\circ} \mathrm{C}$, in June $20.7^{\circ} \mathrm{C}$. There was a relatively good water supply through all the season for oilseed rape growth. 
Soil at the experimental field is medium heavy to heavy (33.3\% sand, $40.3 \%$ silt, $26.4 \%$ gley). At the beginning of the experiment soil analyze was performed (Table 2) and Nmin content in soil was detected. In the upper $25 \mathrm{~cm}$ of soil there was $20 \mathrm{~kg} / \mathrm{ha} \mathrm{N}-\mathrm{NO}_{3}$ and $26 \mathrm{~kg} / \mathrm{ha} \mathrm{N}-\mathrm{NH}_{4}$ at the end of August 2006. According to the analyze results soil was fertilized by $220 \mathrm{~kg} / \mathrm{ha} \mathrm{K}_{2} \mathrm{O}$, no magnesium, phosphorus and boron fertilization was performed.

Nitrogen was applied at three side-dressings: $50 \mathrm{~kg} / \mathrm{ha} \mathrm{N}$ at sowing, $80 \mathrm{~kg} / \mathrm{ha} \mathrm{N}$ in spring and 50 $\mathrm{kg} / \mathrm{ha} \mathrm{N}$ at the beginning of flowering. Before both spring $\mathrm{N}$ side-dressings $\mathrm{Nmin}$ was detected. In soil there was $6 \mathrm{~kg} / \mathrm{ha} \mathrm{N}-\mathrm{NO}_{3}$ and $20 \mathrm{~kg} / \mathrm{ha} \mathrm{N}-\mathrm{NH}_{4}$ in the beginning of March 2007 and 20 $\mathrm{kg} / \mathrm{ha} \mathrm{N}-\mathrm{NO}_{3}$ and $37 \mathrm{~kg} / \mathrm{ha} \mathrm{N}-\mathrm{NH}_{4}$ in April.

Table 2: Soil analyze results at the conduction of the experiment in August 2006

\begin{tabular}{|c|c|c|c|c|c|c|}
\hline $\begin{array}{l}\text { Sampling } \\
\text { depth }(\mathrm{cm})\end{array}$ & $\begin{array}{c}\mathrm{pH} \\
\text { in } \mathrm{KCl}\end{array}$ & $\begin{array}{c}\mathrm{P}_{2} \mathrm{O}_{5} \\
\text { (mg/100 g } \\
\text { soil) }\end{array}$ & $\begin{array}{c}\mathrm{K}_{2} \mathrm{O} \\
\text { (mg/100 g } \\
\text { soil) }\end{array}$ & $\begin{array}{c}\mathrm{MgO} \\
\text { (mg/100 g } \\
\text { soil) }\end{array}$ & $\begin{array}{c}\mathrm{B} \\
\begin{array}{c}\mathrm{mg} / 100 \mathrm{~g} \\
\text { soil) }\end{array}\end{array}$ & $\begin{array}{c}\text { Total S } \\
\text { (mg/100 g } \\
\text { soil) }\end{array}$ \\
\hline $0-30$ & 6,9 & $44 \mathrm{E}^{*}$ & $24 \mathrm{C}^{*}$ & $16,9 \mathrm{C}^{*}$ & $1,3 \mathrm{D}^{*}$ & 49 \\
\hline
\end{tabular}

\section{RESULTS AND DISCUSSION}

\subsection{Grain yield}

Higher yield of grain for $540 \mathrm{~kg} / \mathrm{ha}$ in the average of six treatments (Table 3) was reached by variety Smart compared to hybrid Toccata. The way of S fertilization impacted the two investigated oilseed rapes differently. Yield responses were not consistent among cultivars in the experiment by Asare and Scarisbrick (1995), too. It seems that in our experiment $S$ fertilization did not impacted seed yield at variety Smart, while positive effects of gypsum applications at sowing $(50 \mathrm{~kg} / \mathrm{ha}$ or $20 \mathrm{~kg} / \mathrm{ha}$ S) were detected at hybrid Toccata, although the differences could not be statistically confirmed. It was detected that $\mathrm{S}$ fertilization in spring reflected in lower yields of grain at hybrid Toccata, but the differences in the yields compared to the control could not be statistically confirmed. Probably S content in soil at the conduction of the experiment was high enough, so additional $\mathrm{S}$ fertilization did not impacted yield importantly.

In the experiment by Donald et al. (1993) there were no significant effects on crop yield as a result of applied $\mathrm{S}$, probably due to a significant input of atmospheric $\mathrm{S}$ in that year, as the authors concluded. On the other hand in the experiment by Withers and Odonnell (1994) seed yield of double-low winter oilseed rape was significantly improved by $\mathrm{S}$ applications by $10-17 \%$ on sandy soils with severe $\mathrm{S}$ deficiency symptoms, while seed yield was consistently but not significant increased by an average of $8 \%$ on a shallow calcareous soil which did not show $\mathrm{S}$ deficiency symptoms. The effect of $\mathrm{S}$ on the yield was significant in the experiment by McGrath and Zhao (1996). The yield benefits were obtained mainly from the application of the first $10 \mathrm{~kg} / \mathrm{ha} \mathrm{S}$ and further yield increases were unlikely above 40 $\mathrm{kg} /$ ha $\mathrm{S}$. At the same time seed yield was not increased by $\mathrm{S}$ at zero or low (up to $100 \mathrm{~kg} / \mathrm{ha} \mathrm{N}$ ) N rates. 
At the variety Smart slight better results were indicated when sulphur fertilizers were applied at sowing compared to spring applications (Figure 1). At hybrid Toccata better results were indicated gypsum compared to $\mathrm{K}_{2} \mathrm{SO}_{4}$. At variants where sulphur fertilizers were applied in spring, lower yields were detected maybe because these two treatments were damaged by snow in March the most. Split amount of sulphur in the form of gypsum resulted in the lowest yield at the cultivar and the highest at the hybrid. This occurrence should be subject for the following investigations.

Table 3: Yields of grain (DM), oil content $(\%)$, oil yield $(\mathrm{kg} / \mathrm{ha})$, crude protein content $(\%)$ and protein yield $(\mathrm{kg} / \mathrm{ha})$ at winter oilseed rape (variety Smart and hybrid Toccata; Slovenian Institute of Hop Research and Brewing, June, 2007)

\begin{tabular}{|c|c|c|c|c|c|c|c|c|c|c|}
\hline \multirow{2}{*}{$\begin{array}{l}\text { Fertilization } \\
\text { by sulphur }\end{array}$} & \multicolumn{2}{|c|}{$\begin{array}{l}\text { Yield of grain } \\
\text { (kg/ha DM) }\end{array}$} & \multicolumn{2}{|c|}{ Oil content $(\%)$} & \multicolumn{2}{|c|}{ Oil yield (kg/ha) } & \multicolumn{2}{|c|}{$\begin{array}{c}\text { Crude proteins } \\
(\%)\end{array}$} & \multicolumn{2}{|c|}{$\begin{array}{l}\text { Crude proteins } \\
(\mathrm{kg} / \mathrm{ha})\end{array}$} \\
\hline & $\begin{array}{c}\text { Cultivar } \\
\text { Smart } \\
\end{array}$ & $\begin{array}{l}\text { Hybrid } \\
\text { Toccata }\end{array}$ & $\begin{array}{c}\text { Cultivar } \\
\text { Smart } \\
\end{array}$ & $\begin{array}{l}\text { Hybrid } \\
\text { Toccata }\end{array}$ & $\begin{array}{l}\text { Cultivar } \\
\text { Smart } \\
\end{array}$ & $\begin{array}{l}\text { Hybrid } \\
\text { Toccata }\end{array}$ & $\begin{array}{l}\text { Cultivar } \\
\text { Smart } \\
\end{array}$ & $\begin{array}{l}\text { Hybrid } \\
\text { Toccata }\end{array}$ & $\begin{array}{l}\text { Cultivar } \\
\text { Smart } \\
\end{array}$ & $\begin{array}{l}\text { Hybrid } \\
\text { Toccata }\end{array}$ \\
\hline $\begin{array}{l}\text { No } \\
\text { fertilization } \\
\text { by sulphur }\end{array}$ & $3887 a^{*}$ & $3106 a$ & $44.2 a$ & $40.9 a b$ & 1718 & 1269 & $17.4 a$ & $18.1 a$ & 700 & 600 \\
\hline $\begin{array}{l}\text { Gypsum at } \\
\text { sowing } \\
(50 \mathrm{~kg} / \mathrm{ha} \\
\text { S) }\end{array}$ & $3846 a$ & $3861 a$ & $43.4 a$ & $42.4 b$ & 1671 & 1637 & $16.0 a$ & $18.1 a$ & 653 & 731 \\
\hline $\begin{array}{l}\mathrm{K}_{2} \mathrm{SO}_{4} \text { at } \\
\text { sowing } \\
(50 \mathrm{~kg} / \mathrm{ha} \\
\text { S) }\end{array}$ & $3982 a$ & $3080 a$ & $43.6 a$ & $39.1 a$ & 1737 & 1204 & $17.8 a$ & $18.3 a$ & 701 & 561 \\
\hline $\begin{array}{l}\text { Gypsum in } \\
\text { spring } \\
(50 \mathrm{~kg} / \mathrm{ha} \\
\text { S) }\end{array}$ & $3617 a$ & $2437 a$ & $42.8 a$ & $39.7 a b$ & 1547 & 967 & $16.6 a$ & $18.8 a$ & 669 & 450 \\
\hline $\begin{array}{l}\mathrm{K}_{2} \mathrm{SO}_{4} \text { in } \\
\text { spring } \\
(50 \mathrm{~kg} / \mathrm{ha} \\
\mathrm{S})\end{array}$ & $3797 a$ & $2827 a$ & $44.3 a$ & $39.7 a b$ & 1682 & 1123 & $18.5 a$ & $18.2 a$ & 699 & 530 \\
\hline $\begin{array}{l}\text { Gypsum at } \\
\text { sowing } \\
(20 \mathrm{~kg} / \mathrm{ha} \\
\mathrm{S}) \text { and in } \\
\text { spring ( } 30 \\
\mathrm{~kg} / \mathrm{ha} \mathrm{S})\end{array}$ & $3241 a$ & $3874 a$ & $42.3 a$ & $38.9 a$ & 1372 & 1508 & $15.5 a$ & $18.4 a$ & 574 & 758 \\
\hline
\end{tabular}

\subsection{Protein content and protein yield}

There were no significant differences among treatments in the crude protein content, while there were important differences among blocks - soil characteristics had an important impact on the crude protein content; in the third block the average value of all six treatments was lower compared to the average value of the first and the second block what brought high variability in the results. At the cultivar Smart a 
trend of increasing crude protein content was detected with postponing the time of sulfur fertilization, while no such trend was detected at the hybrid Toccata. Exceeding sulphur rate caused lowering in the crude protein content; at the variant $10 \mathrm{x} \mathrm{S}(500 \mathrm{~kg} / \mathrm{ha} \mathrm{S}$ in the form of gypsum) $14.8 \%$ of crude protein content was detected.

At the cultivar Smart $\mathrm{S}$ fertilization seemed to impact rather negatively on the protein yield, but the differences among treatments could not be statistically confirmed (Table 3). At the hybrid Toccata gypsum as the source of $\mathrm{S}$ gave better results compared to $\mathrm{K}_{2} \mathrm{SO}_{4}$ when observing protein yield, but differences among treatments could not be statistically confirmed. Protein yield was impacted positively by gypsum applications at sowing or in a split dose, while spring application of gypsum in a whole dose of S reflected in lowering its protein yield. Applications of the whole amount of $\mathrm{S}$ in spring reflected in lowering the protein yield compared to the control (no $\mathrm{S}$ fertilization).

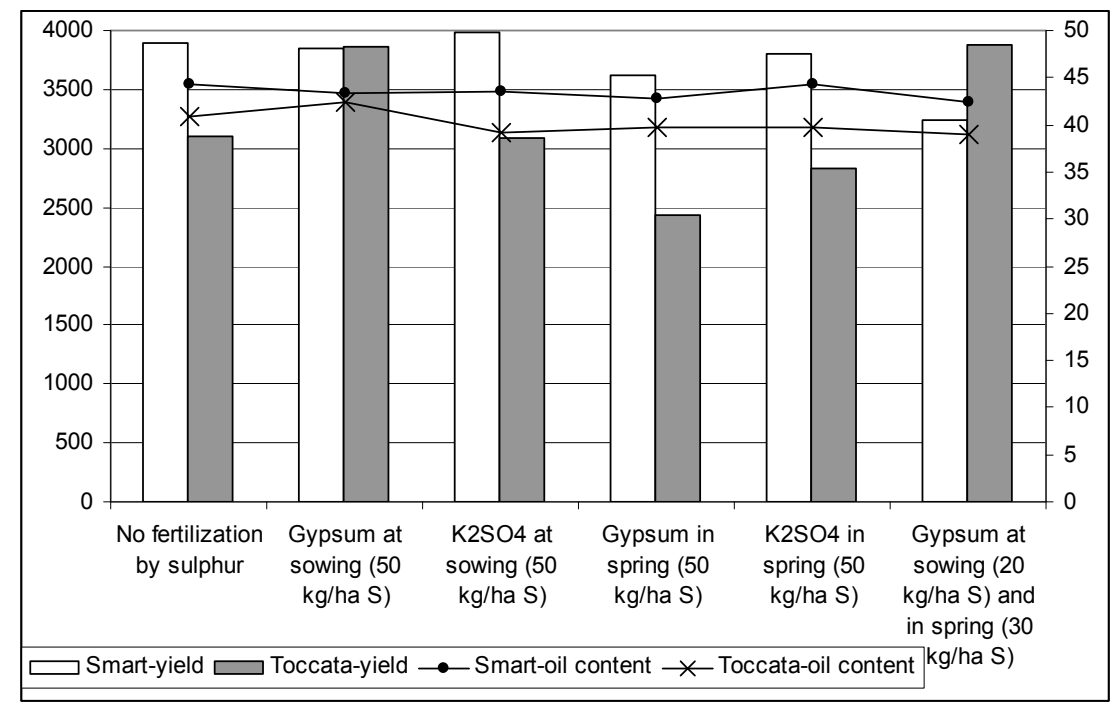

Figure 1: Yield (kg/ha DM) and oil content (\% DM) at oilseed rape cultivar Smart and hybrid Toccata (Slovenian Institute of Hop Research and Brewing, June 2007)

\subsection{Oil content and oil yield}

There was higher oil content at the cultivar Smart compared to the hybrid Toccata by $3.32 \%$ in the average of six treatments. There were no differences in oil content among treatments at the cultivar Smart while it seemed that gypsum applications at sowing positively impacted oil content at the hybrid Toccata. The latest could not be said in the case of split gypsum applications and applications of $\mathrm{K}_{2} \mathrm{SO}_{4}$. 
In the experiment by Zhao et al. (1993) applications of $\mathrm{S}$ had no significant influences on seed yield and oil content at the S-sufficient site while at the Sdeficient site there were significant interactions between $\mathrm{S}$ and $\mathrm{N}$ on seed yield. Application of S increased oil content in one of three investigated seasons when the degree of $\mathrm{S}$ deficiency was particularly severe in the experiment by McGrath and Zhao (1996). The $S$ treatments $(0-80 \mathrm{~kg} / \mathrm{ha} \mathrm{S})$ decreased oil content by an average maximum of $9 \mathrm{mg} / \mathrm{g}$ in the experiment by Withers and Odonnell (1994). Sulphur application did not influence oil contents in the experiment by Asare and Scarisbrick (1995).

Samples of oil with the highest and the lowest oil content at both included oilseed rapes were analysed on the presence of fatty acids (Table 4). There were no detectable differences between the samples of the same oilseed rape, while there were differences between cultivar Smart and hybrid Toccata. The difference appeared in the content of oleic acid which represented the highest share in oils in all cases. It seems that at the hybrid Toccata higher share of nonsaturated fatty acids is formed compared to the cultivar Smart.

Table 4: Fatty acids content (\%) at the cultivar Smart and hybrid Toccata (Slovenian Institute of Hop Research and Brewing, June, 2007)

\begin{tabular}{lcccc}
\hline & \multicolumn{2}{c}{ Cultivar Smart (\%) } & \multicolumn{2}{c}{ Hybrid Toccata (\%) } \\
& Maximal & Minimal & Maximal & Minimal \\
\hline C 16:0 (palmitic & 4.6 & 4.6 & 4.8 & 4.7 \\
acid) & 1.7 & 1.5 & 1.6 & 1.3 \\
C 18:0 (stearic acid) & 67.1 & 66.8 & 64.7 & 63.7 \\
C 18:1 (oleic acid) & 6.7 & 16.5 & 19.1 & 18.7 \\
C 18:2 (linoleic & 16.7 & & & \\
acid) & 7.9 & 7.5 & 8.0 & 8.0 \\
C 18:3 (linolenic & & & & \\
acid)
\end{tabular}

Oil yield was comparable between the control and when applying $\mathrm{K}_{2} \mathrm{SO}_{4}$ at sowing, all the other variants of $\mathrm{S}$ fertilization seemed to lower oil yield at cultivar Smart. At hybrid Toccata gypsum as the source of $\mathrm{S}$ gave better results compared to control or $\mathrm{K}_{2} \mathrm{SO}_{4}$ as the source of $\mathrm{S}$, while application of gypsum in a split dose reflected in the lowest oil yield at that hybrid, but the differences among treatments could not be statistically confirmed.

\section{CONCLUSIONS}

Applications of $50 \mathrm{~kg} / \mathrm{ha} \mathrm{S}$ in the form of gypsum did not significantly impacted the yield of seed (Duncan multiple range test, $p<0.05$ ) at the two investigated cultivars of oilseed rapes (cultivar Smart and hybrid Toccata). At cultivar Smart negative impact of spring fertilization by sulphur was detected, while there was a positive impact of gypsum applications at sowing at hybrid Toccata. Oil content was higher 
at cultivar Smart compared to hybrid Toccata by 3.32\%. At cultivar Smart oil content was relatively the same at all six investigated variants $(42.3 \%$ to $44.3 \%)$, at hybrid Toccata differences in oil content among variants were significant $(38.9 \%$ to 42.4\%). At cultivar Smart no fertilization variant impacted importantly the yield of oil, at hybrid Toccata positive impact of spring fertilization by sulphur on the yield of oil was detected. Oil yield was importantly higher at cultivar Smart compared to the hybrid Toccata. Protein content was not impacted by sulphur applications, it was higher at hybrid Toccata compared to cultivar Smart by $1.35 \%$. Because of the higher seed yield at cultivar Smart protein yield was higher at the latest compared to the hybrid Toccata. Different responses of oilseed rape to sulphur applications are reported by other authors, too. The share of linoleic acid was higher at hybrid Toccata by $2.2 \%$ to $2.4 \%$, the share of oleic acid was higher at cultivar Smart by $2.2 \%$ to $3.1 \%$, shares of other investigated acids did not differ a lot between Smart and Toccata.

\section{LITERATURE}

Ahmad, A., Abrol, YP., Abdin, MZ. (1999): Effect of split application of sulphur and nitrogen on growth and yield attributes of Brassica genotypes differing in time of flowering. Canadian Journal of Plant Science, 79, 2: 175-180.

Asare, E., Scarsbrick, DH. (1995): Rate of nitrogen and sulphur fertilizers on yield, yield components and seed quality of oilseed rape (Brassica napus L.). Field Crops Research, 44, 1: 41-46.

Bradstreet, R. B. (1954): Kjeldahl Method for Organic Nitrogen. Analytical Chemistry, 26, 1.

Donald, D., Sharp, GS., Atkinson, D., Duff, EI. (1993): Effect of nitrogen and sulphur fertilization on the yield and composition of winter oilseed rape. Communications in Soil Science and Plant Analysis, 24, 9-10: 813-826.

Fageria, NK., Baligar, VC. (2001): Improving nutrient use efficiency of annual crops in Brazilian acid soils for sustainable crop production. Communications in Soil Science and Plant Analysis, 32, 7-8: 1303-1319.

Hamilton, S., Hamilton, R.J., Sewell, P.A. (1992): Extraction of lipids and derivate formation in Lipid Analysis-a practical approach, Hamilton, S., Hamilton, R.J., eds., chapter 7, Oxford University Press, Oxford.

Hamza, M.A., Andreson, W.K. (2002): Improving soil physical fertility and crop yield on a clay soil in Western Australia. Australian Journal of Agricultural Research, 53, 5: 615-620.

Hamza, M.A., Andreson, W.K. (2003): Responses of soil properties and grain yields to deep ripping and gypsum application in a compacted loamy sand soil contrasted with a sandy clay loam soil in Western Australia. Australian Journal of Agricultural Research, 54, 3: 273-282.

Intodia, SK., Tomar, OP. (1997): Effect of sulphur application on growth and yield of sunflower (Helianthus annuus L.). Indian Journal of Agricultural Science, 67, 1:4647.

ISO 659:1998 Oilseeds -- Determination of oil content (Reference method). 
ISO 665:1977, Oilseeds -- Determination of moisture and volatile matter content.

Kowalenko, CG. (2004): Response of grass to sulphur applications on coastal British Columbia soils. Canadian Journal of Soil Science, 84, 2: 227-236.

McGrath, SP., Zhao, FJ. (1996): Sulphur uptake, yield response and the interactions between nitrogen and sulphur in winter oilseed rape (Brassica napus). Journal of Agricultural Science, 126: 53-62.

Moreira, A., Evangelista, AR., De Carvalho, JG. (1998): Effect of sulphur sources on yield and mineral composition of white clower. Pesquisa Agropecuaria Brasileira, 33, 7: $1137-1142$.

Rao, SS., Shaktawat, MS. (2002). Residual effect of organic manure, phosphorus and gypsum application in preceding groundnut (Arachis hypogaea) on soil fertility and productivity of Indian mustard (Brassica juncea). Indian Journal of Agronomy, 47, 4: $487-494$

Samui, RC., Bandopadhyay, P. (1997): Effect of source level and method of application of sulphur on Indian mustard (Brassica juncea). Indian Journal of Agricultural Sciences, 67, 8: 305-307.

Sanderson, KR., Carter, MR. (2002): Effect of gypsum and elemental sulphur on calcium and sulphur content of rutabagas in Podzolic soils. Canadian Journal of Plant Science, 82, 4: 785-788.

Sanderson, KR., Sandreson, JB., Ivany, JA. (1996): Supplemental soil sulphur increases cabbage yield. Canadian Journal of Plant Science, 76, 4: 857-859.

Shekhawat, PS., Rathore, AS., Singh, M. (1996): Effect of source and level of sulphur on yield attributes and seed yield of clusterbean (Cyamopsis tetragonoloba) under rainfed conditions. Indian Journal of Agronomy, 41, 3: 424-426.

Singh, SP., Chauhan, DS. (2002): Response of lentil (Lens culinaris) cultivars to sources and levels of sulphur. Indian Journal of Agronomy, 47, 1: 94-97.

Singh, YP., Aggarwal, RL. (1998): Effect of sulphur sources and levels on yield, nutrient uptake and quality of blackgram (Phaseolus mungo). Indian Journal of Agronomy, 43, 3: 448-452.

Withers, PJA., Odonnell, FM. (1994): The response of double-low winter oilseed rape to fertilizer sulphur. Journal of the Science of Food and Agriculture, 66, 1: 93-101.

Withers, PJA., Tytherleigh, ARJ., ODonnell, FM. (1995): Effect of sulphur fertilizers on the grain yield and sulphur content of cereals. Journal of Agricultural Science, 125: 317-324.

Zhao, FJ., Evans, EJ., Bilsborrow, PE., Syers, JK. (1993): Influence of sulphur and nitrogen on seed yield and quality of low glucosinolate oilseed rape (Brassica napus). Journal of the Science of Food and Agriculture, 63, 1: 29-37.

Zhao, FJ., Withers, PJA., Evans, EJ., Monaghan, J., Salmon, SE., Shewry, PR., McGrath, SP. (1997): Sulphur nutrition: An important factor for the quality of wheat and rapeseed. Soil Science and Plant Nutrition, 43: 1137-1142. 